\title{
Pengembangan Sikap Keberagamaan Peserta Didik
}

\author{
Sutarto \\ Institut Agama Islam Negeri (IAIN) Curup \\ seotartoo74@gmail.com
}

\begin{abstract}
This paper aims to reveal the nature of religious attitudes, factors that affect the attitude of religious, characteristics and development, the components and forms and how to develop the attitude of religious learners. The method used is library research and analyzed by reflective thinking. Based on the findings can be seen that the attitude of religious learners basically an internal state that exists in the learners that formed through interaction with the environment. The characteristics and development of the religious attitudes of each learner vary according to the stages of development. These differences can be seen from the cognitive, affective and conative aspects. Establishment and development of a stance must begin early and be done according to their cognitive characteristics, emotions and level of consciousness. There are two ways that can be done to grow and develop the attitude of religious learners, namely: First, the internalization of Islamic values. Internalization of Islamic values can be done by giving exemplary, suggestive and correction and social impulse. Second, creating a religious environment in the family, school and community.
\end{abstract}

Keywords: Religious Attitude, Learners

Abstrak : Tulisan ini bertujuan untuk mengungkapkan tentang hakekat sikap keberagamaan, faktor-faktor yang mempengarugi sikap keberagamaan, karakteristik dan perkembangan, komponen-komponen dan bentuk-bentuk serta cara mengembangkan sikap keberagamaan peserta didik. Metode yang digunakan adalah library research dan dianalisis dengan reflektif thinking. Berdasarkan temuan, dapat diketahui bahwa sikap keberagamaan peserta didik pada dasarnya merupakan keadaan internal yang ada dalam dari peserta didik yang terbentuk melalui interaksi dengan lingkungan. Karakteristik dan perkembangan sikap keberagamaan setiap peserta didik berbeda-beda sesuai dengan tahap-tahap perkembangan. Perbedaan tersebut dapat dilihat dari aspek kognitif, afektif dan konatif. Pembentukan dan pengembangan sikap keberagaan harus dimulai sejak dini dan dilakukan sesuai dengan karakteristik kognitifnya, emosinya dan tingkat kesadaran beragamanya. Ada dua cara yang dapat dilkukan untuk menumbuhkan dan mengembangkan sikap keberagamaan peserta didik, yaitu : Pertama, internalisasi nilai-nilai keislaman. Internalisasi nilai-nilai keislaman dapat dilakukan dengan memberikan keteladanan, sugesti dan koreksi

ISLAMIC COUNSELING : Jurnal Bimbingan dan Konseling Islam vol. 2, no. 1, 2018 | p ISSN 2580-3638; e ISSN 2580-3646

http://journal.staincurup.ac.id/index.php/JBK 
dan dorongan sosial. Kedua, menciptakan lingkungan religius baik di keluarga, sekolah maupun di masyarakat.

Kata Kunci : Sikap Keberagamaan, Peserta Didik

\section{Pendahuluan}

Sikap keberagamaan memiliki peran yang sangat penting dalam pembentukan perilaku keberagamaan. Sikap keberagamaan yang baik akan memunculkan perilaku keberagaan yang baik. Begitu juga sebaliknya, sikap keberagamaan yang kurang baik akan memunculkan perilaku keberagamaan yang kurang baik pula. Oleh karena itu untuk membentuk perilaku keberagamaan individu harus dimulai dari pembentukan sikap kegeragamaan.

Dilihat dari aspek perkembangan, setiap individu memiliki karakteristik yang berbeda-beda. Perbedaan tersebut dapat dilihat dari tingkat perkembangan, tugas perkembangan dan karakteristik masing-masing tingkat perkembangan. Dengan adanya perbedaan tersebut akan mempengaruhi cara dan pendekatan yang digunakan dalam pembentukan sikap, termasuk dalam pembentukan sikap keberagamaan. Memahami hakikat sikap keberagamaan, karakteristik dan komponen sikap keberagamaan pada setiap tingkat perkembangan, faktorfaktor yang mempengaruhi serta cara mengembangkan sikap keberagamaan individu sangat penting untuk dilakukan terutama bagi guru.

Namun kenyataannya kata sikap sering kali digunakan dalam pengertian yang kurang tepat. Misalnya Ahmad sikapnya lemah. Murid dihukum guru karena bersikap nakal dan sebagainya. Dalam kajian psikologi, sikap pada hakekatnya adalah suatu keadaan yang bersifat internal (di dalam) dari manusia yang menyebabkan munculnya kesiapan untuk merespon suatu objek tertentu, baik secara positif maupun secara negatif.

Kata sikap atau "attitude" (dalam bahasa Inggris) pertama sekali dipopulerkan oleh Harbert Spencer (1862) untuk menunjukkan situasi mental seseorang. ${ }^{1}$ Pada tahun 1888, konsep ini digunakan oleh Lange dalam suatu eksprimen di laboratorium. ${ }^{2}$ Pada perkembangan selanjutnya, konsep sikap lebih popular digunakan ahli sosiologi dan psikologi. Ahli psikologi beralasan bahwa sikap menjadi alasan utama munculnya perbedaan perilaku setiap individu. Individu memiliki perilaku yang berbeda, salah satu penyebabnya adalah karena inidividu memiliki sikap yang berbeda terhadap suatu objek tertentu. Para ahli sosiologi, sikap memiliki arti yang sangat penting, khususnya dalam menerangkan perubahan sosial dan budaya. Begitu juga halnya dengan tingkah laku individu dalam beragama, juga berbeda-beda. Salah satu penyebabnya adalah individu memiliki sikap keberagamaan berbeda-beda.

\footnotetext{
${ }^{1}$ Saifuddin Azwar, Sikap Manusia: Teori dan Pengukurannya, (Yogyakarta: Pustaka Pelajar, 1995), h. 3

${ }^{2}$ Ibid., h. 4
} 
Sikap keberagamaan bukan merupakan bawaan, melainkan bentukan setelah individu lahir. Pembentukan sikap keberagamaan harus dimulai sejak dini. Sebab, pada masa awal merupakan masa yang sangat penting. Menurut Sigmund Freud, masa-masa awal menrupakan masa pembentukan dasar-dasar sikap, kebiasaan, keperibadian dan tingkah laku. Apabila pada dasar-dasar sikap, kebiasaan, kepribadian dan tingkah laku sudah terbentuk pada masa-masa awal dengan baik, maka akan mempermudah perkembangan untuk masa-masa selanjutnya. ${ }^{3}$

Penelitian terkait dengan sikap keberagamaan sudah banyak dikemukakan, diantaranya adalah penelitian yang dilakukan oleh Noer, H. A., Tambak, S., dan Rahman, H. (2017) dengan judul penelitian Upaya Ekstrakurikuler Kerohanian Islam (ROHIS) dalam Meningkatkan Sikap Keberagamaan Siswa di SMK Ibnu Taimiyah Pekanbaru. Penelitian ini menekankan pada upaya meningkatkan sikap keberagamaan siswa SMK melalui kegiatan kegiatan Ekstrakurikuler Kerohanian Islam (ROHIS). Temuan penelitian menunjukkan bahwa $82.25 \%$ kegiatan Ekstrakurikuler Kerohanian Islam (ROHIS) dapat meningkatkan sikap keberagamaan siswa. ${ }^{4}$ Tampubolon, I. (2016), Struktur Paradigmatik Ilmu-ilmu Keislaman Klasik: Dampaknya terhadap Pola Pikir, Sikap, dan Perilaku Keberagamaan. Tujuan penelitian ini adalah untuk melihat pengaruh Ilmu-ilmu Keislaman Klasik terhadap Pola Pikir, Sikap, dan Perilaku Keberagamaan seseorang. Hasil penelitian mengemukakan bahwa pola fikir keilmuan Islam klasik berpengaruh terhadap tembentukan corak pemahaman, sikap dan perilaku keberagamaan seseorang. ${ }^{5}$

Penelitian lain juga dilakukan Arham, A. (2016), dengan judul penelitian Pengaruh Pembinaan Kehidupan Beragamaan dalam Keluarga terhadap Sikap Keberagamaan Peserta Didik SDN 74 Tamarellang Auladuna. Penelitian ini bertujuan untuk melihat pengaruh pembinaan kehidupan beragama dalam keluarga terhadap sikap keberagamaan peserta didik. Berdasarkan penelitian ini pembinaan kehidupan beragaman dalam keluarga sangat mempengaruhi sikap keberagamaan siswa. ${ }^{6}$ Ismail dan Fahmi, Internalisasi Sikap Keberagamaan sejak Usia Dini. Penelitian ini berupaya mengungkapkan pentingnya internalisasi nilainilai akidah, ibadah dan akhlak pada anak usia dini (0-6 tahun). Hasil penelitian

\footnotetext{
${ }^{3}$ Santrock, Perkembangan Masa Hidup Jilid I, (Jakarta, Erlangga : 2004), h. 36

${ }^{4}$ Noer, H. A., Tambak, S., \& Rahman, H. (2017). Upaya Ekstrakurikuler Kerohanian Islam (ROHIS) dalam Meningkatkan Sikap Keberagamaan Siswa di SMK Ibnu Taimiyah Pekanbaru. Jurnal Pendidikan Agama Islam Al-Thariqah, 2(1), 21-38.

5 Tampubolon, I. (2016). Struktur Paradigmatik Ilmu-ilmu Keislaman Klasik: Dampaknya terhadap Pola Pikir, Sikap, dan Perilaku Keberagamaan. MIQOT: Jurnal Ilmu-ilmu Keislaman, 37(2).

${ }^{6}$ Arham, A. (2016). Pengaruh Pembinaan Kegidupan Beragamaan dalam Keluarga terhadap Sikap Keberagamaan Peserta Didik SDN 74 Tamarellang Auladuna: Jurnal Pendidikan Dasar Islam, 3(1), 11-15.
} 
menunjukkan bahwa internalisasi sikap keberagamaan baik aspek akidah, ibadah dan akhlak sangat penting dilakukan mulai usia dini serat dapat mempengaruhi pertumbuhan dan perkembangan tahap selanjutnya. ${ }^{7}$ Irwansyah, I. (2014), Perbedaan Sikap Keberagamaan Antara Masyarakat Islam dan Kristiani di Sumatera Utara dan Frankfurt Am Main Jerman. Tujuan penelitian ini adalah untuk melihat perbedaan sikap keberagamaan masyarakat muslim dan Kristiani khususnya di Sumatera Utara. Temuan penelitian menunjukkan bahwa terdapat perbedaan yang siknifikan antara sikap keberadamaan masyarakat Islam dan Kristiani di Sumatera Utara dan Frankfurt Am Main Jerman. ${ }^{8}$

Berdasarkan penelitian terdahulu sebagaimana dikemukakan di atas, dapat dikatakan bahwa penelitian tentang sikap sudah banyak dilakukan, namun belum ada yang secara spesifik membahas tentang pengembangan sikap keberagamaan peserta didik dari semua rentang kehidupan. Tulisan ini akan membahas tentang apa sesungguhnya sikap keberagamaan itu? Apa saja yang mempengarugi sikap keberagamaan peserta didik? Bagaimana karakteristik dan perkembangan sikap keberagamaan peserta didik? Apa saja komponen dan bentuk-bentuk sikap keberagamaan? Bagaimana cara mengembangkan sikap keberagamaan peserta didik? Pertanyaan-pertanyaan tersebut akan dijawab dengan menggunakan pendekatan library research dan dianalisis dengan reflektif thinking.

\section{Pengembangan Sikap Keberagamaan Peserta Didik}

\section{Pengertian sikap keberagamaan}

Setiap individu dalam berinteraksi dengan individu lain, selalu menyadari terhadap apa yang dilakukannya dan terhadap situasi yang ada di sekelilingnya. Kesadara tersebut bukan hanya berkaitan dengan perbuatan yang sedang terjadi, melainkan juga perbuatan yang mungkin akan dilakukan. Kesadara untuk menentukan perbuatan yang sedang dilakukan maupun perbuatan yang akan dilakukan tersebut dinamakan dengan sikap. Dengan kata lain, sikap adalah penentu sifat dan hakekat perbuatan yang sedang maupun yang akan dilakukan oleh seseorang.

W.J. Thomas sebagaimana dikutip oleh Saifiddin Azwar, memberikan batasan bahwa, sikap merupakan kesadaran individu dalam menentukan perbuatan nyata (sedang dilakukan) maupun perbuatan yang akan dilakukan dalam berinteraksi dengan individu lainnya.' Ini berarti, sikap seseorang

${ }^{7}$ Ismail dan Fahmi (2017). Internalisasi Sikap Keberagamaan sejak Usia Dini, Vol 1 No. 1: Raudhatul Athfal: Jurnal Pendidikan Islam Anak Usia Dini: jurnal.radenfatah.ac.id

${ }^{8}$ Irwansyah, I. (2014). Perbedaan Sikap Keberagamaan Antara Masyarakat Islam dan Kristiani di Sumatera Utara dan Frankfurt Am Main Jerman. ISLAMICA: Jurnal Studi Keislaman, 9(1), 30-53.

${ }^{9}$ Saifuddin Azwar, Sikap Manusia: Teori dan Pengukurannya...h. 29 
seringkali diarahkan pada suatu objek tertentu. Tidak akan muncul sikap tanpa adanya suatu objek. Misalnya: sikap anak terhadap orang tua, sikap murid terhadap guru dan sebagainya.

Pendapat senada dikemukakan oleh Soekodjo. N, (dalam Jalaludin) Sikap adalah respon atau reaksi seseorang terhadap objek atau stimulus tertentu yang masih bersifat tertutup. ${ }^{10} \quad$ Newcomb (dalam Saifuddin Azwar) mengatakan, sikap ialah kesiapan atau kesediaan untuk melakukan suatu tindakan." Secara singkat dapat dikatakan, sikap baru merupakan "predisposisi" suatu tindakan atau perilaku seseorang yang masih berbentuk reaksi tertutup dan belum berbentuk reaksi terbuka.

Hal senada dikemukakan oleh Saifuddin. Azwar. Saifuddin Azwar. menjelaskan bahwa sikap merupakan reaksi seseorang terhadap suatu objek, reaksi tersebut dapat berbentuk perasaan (afeksi), pemikiran (kognisi) dan predisposisi tindakan (konasi). ${ }^{12}$ Menurut Gagne (dalam Jalaludin) sikap adalah suatu keadaan internal (internal state) yang mempengaruhi pilihan tidakan individu dalam merespon suatu objek. ${ }^{13}$

Ellis sebagaimana dikutip oleh M. Ngalim Purwanto menjelaskan bahwa, hal yang memiliki peran yang sangat penting berkaitan dengan sikap adalah perasaan atau emosi dan reaksi/respon atau kecenderungan beraksi. ${ }^{14}$ Sikap pada hakekatnya adalah keadaan internal sebagai penentu tingkah laku manusia dalam merespon stimulus. Keadaan internal tersebut menyebabkan munculnya kesiapan untuk merespon suatu objek tertentu, baik secara positif maupun secara negatif. Misalnya seorang muslim memiliki sikap negatif terhadap daging babi, karena haram, najis dan kotor, maka akan muncul respon atau tingkah laku menjauhi, menghindari, menolak dan sebagainya.

Sikap seseorang berbeda-beda dalam merespon suatu rangsangan. Perbedaan tersebut disebabkan karena adanya perbedaan minat, pengalaman, pengetahuan, intensitas perasaan, situasi lingkungan dan sebagainya. Begitu juga halnya sikap seseorang terhadap rangsangan yang sama, kemungkinan juga akan memunculkan sikap yang tidak sama pula. Termasuk sikap keberagamaan seseorang juga berbeda-beda.

Keberagamaan berasal dari kata "beragama" yang berarti hidup tidak kacau yakni selalu berhaluan/beraturan. ${ }^{15}$ Endang Saifuddin Anshari

${ }^{10}$ Jalaludin, Psikologi Agama, (Jakarta: Rajawali Press, 2011), h. 118

${ }^{11}$ Saifuddin Azwar, Sikap Manusia: Teori dan Pengukurannya...h. 29

${ }^{12}$ Ibid., h. 30

13 Jalaludin, Psikologi Agama...h. 118.

${ }_{14}$ M. Ngalim Purwanto, Psikologi Pendidikan, (Bandung : PT Remaja Rosdakarya, 2004), h. 141

${ }^{15}$ Departemen Pendidikan dan Kebudayaan, Kamus Besar Babasa Indonesia, Jakarta: Dep. P dan K, 1991), h, 54 
mengatakan kata keberagamaan berasal dari kata beragama mendapat awalan dan akhiran "ke-an" yang artinya berlandaskan ajaran agama (Islam).16 Jalaludin Rahmad mengemukakan keberagamaan adalah kecenderungan seseorang untuk hidup sesuai dengan aturan agama,17 Menurut Ahmad Tafsir, inti dari keberagamaan adalah sikap beragama, dalam kontek Islam sikap beragama intinya adalah iman.18 Asmaul Sahlan menjelaskan bahwa keberagamaan adalah sikap atau kesadaran seseorang untuk menjalankan ajaran agama yang didasarkan atas keyakinan atau kepercayaan ${ }^{19}$

Sikap keberagamaan adalah keadaan internal atau keadaan yang masih ada dalam dari manusia. Keadaan internal tersebut menyebabkan munculnya kesiapan untuk merespon atau bertingkahlaku sesuai dengan ajaran agama yang diyakininya. Sikap keberagamaan terbentuk karena adanya integrasi secara kompleks antara keyakinan yang kuat terhadap ajaran agama (komponen kognitif), perasaan senang terhadap agama (komponen efektif) dan perilaku yang sesuai dengan ajaran agama (komponen konatif). Menurut Zakiah Darajat, sikap keberagamaan bukan merupakan bawaan, melainkan perolehan atau bentukan setelah lahir. Sikap keberagamaan terbentuk melalui pengalaman langsung melalui interaksi dengan berbagai unsur lingkungan sosial, misalnya hasil kebudayaan, orang tua, guru, teman sebaya, masyarakat dan sebagainya. ${ }^{20}$

\section{Karakteristik dan cara pengukuran sikap keberagamaan}

Di atas sudah dijelaskan bahwa sikap suatu keadaan internal dari individu yang dapat menyebabkan munculnya kesiapan untuk merespon atau bertingkahlaku sesuai dengan ajaran agama yang diyakininya. Sikap keberagamaan dapat berbentuk tanggapan atau perasaan. Sikap keberagamaan biasanya diiringi dengan kecenderungan seseorang untuk bertindak sesuai dengan ajaran agama yang diyakininya.

W. A. Gerungan menjelaskan bahwa, sikap atau attitude memiliki beberapa ciri, yaitu:

a. Sikap bukan merupakan bawaan, melainkan dibentuk dan dipelajari sepanjang perkembangan individu dalam hubungannya dengan objek tersebut.

16 Endang Saifuddin Anshari, Wawasan Islam: Paradigma dan Sistem Islam, Jakarta: Rajawali, 1991), h. 47

17 Jalaludin Rahmad, Psikologi Agama: Sebuah Pengantar,(Jakarta: PT. Raja Grafindo Persada, 2001), h. 116

${ }^{18}$ Ahmad Tafsir, Metodologi Pengajaran Agama Islam, (Bandung: PT. Remaja Rosdakarya, 2005), h. 85

${ }^{19}$ Asmaul Sahlan, Mewrijudkan Budaya Relijius di Sekolab: Upaya mengembangkan PAI dari Teori ke Aksi, (Malang: UIN-Maliki Press, 2009), h. 66

${ }^{20}$ Zakiah Darajat, Ilmu Jiwa Agama, (Jakarta: Bulan Bintang, 2003), h. 58 
b. Sikap dapat dipelajari dan dapat berubah-ubah.

c. Sikap tidak berdiri sendiri, tetapi senantiasa mengandung relasi tertentu terhadap suatu objek.

d. Sikap dapat berkaitan dengan satu objek dan dapat juga berkaitan dengan beberapa objek.

e. Sikap memunculkan dorongan dan perasaan. ${ }^{21}$

Sikap keberagamaan berbeda dengan pengetahuan keagamaan yang dimiliki oleh seseorang. Pengetahuan keberagamaan belum akan menjadi suatu pengerak, sebagaimana pada sikap keberagamaan. Pengetahuan keberagamaan baru akan manjadi suatu sikap keberagamaan, jika disertai dengan kesiapan untuk bertindak sesuai dengan pengetahuan keberagamaan yang dimiliki. Misalnya : Orang mempunyai pengetahuan bahwa bahwa kebersihan sangat bermanfaat bagi kehidupan. Pengetahuan tersebut sudah menjadi sikap jika dalam keseharian selalu mengamalkan hidup bersih. Namun apabila orang tadi tetap senang hidup kotor maka hal tersebut belum dikatakan sebagai sikap.

Sikap keberagamaan memiliki segi motivasi, berarti sikap keberagamaan senantiasa mendorong untuk bergerak dan berusaha untuk mencapai suatu tujuan. Sikap keberagamaan dapat berupa suatu pengetahuan yang diikuti dengan kesediaan dan kecenderungan bertingkahlaku sesuai pengetahuannya itu. Sikap keberagamaan tidak sama dengan kebiasaan tingkah laku beragama. Kebiasaan tingkah laku beragama hanya merupakan tingkah laku yang otomatis dengan tujuan untuk mempermudah hidup.

Sikap keberagamaan setiap individu memiliki karakteristik tersendiri, sesuai dengan tingkat perkembangannya. Anak-anak, remaja dan orang dewasa memiliki karateristik sikap keberagamaan berbeda-beda. Ada beberapa karakteristik sikap keberagamaan pada anak, yaitu :

a. Unreflective atau tidak mendalam. Agama pada anak diterima tanpa kritik dan tidak mendalam. Ajaran agama yang diterima cukup sekedarnya saja, cepat merasa puas dengan keterangan yang diberikan dan kadang- kadang kurang masuk akal. ${ }^{22}$

b. Orientasi Egosentris atau mementingkan dirinya sendiri dan kesenangan pribadinya.

c. Kekonkritan Anthromorphis, yaitu cenderung menterjemahkan kata-kata dan gambar-gambar ke dalam pengalaman yang sudah dijalankan dan berusaha menghubungkan sesuatu yang bersifat abstrak ke dalam pengalaman yang bersifat kongkrit.

${ }^{21}$ W.A. Gerungan, Psikologi Sosial, (Bandung : Rafika Aditama, 2009), h. 163-163

${ }^{22}$ Jalaludin, Psikologi Agama... h. 70 
d. Eksprimental, inisiatif dan spontanitas., yaitu sikap keberagamaan yang bersifat coba-coba dan dilakukan secara spontan. ${ }^{23}$

e. Verbalis dan Ritualis. Kehidupan beragama pada anak bersifat verbal (ucapan). Anak cenderung menghafal secara verbal kalimat-kalimat keagamaan. Amaliah keagamaan yang dikerjakan oleh anak dilaksanakan berdasarkan tuntunan yang diajarkan kepadnya.

f. Imitatif. Pada umumnya kehidupan keseharian anak-anak dalam tindakannya bersifat meniru. Anak-anak lebih cenderung meniru apa yang ada di lingkungan sekitarnya. Baik disadari atau tidak, begitu juga halnya dalam kaitannya dengan sikap keberagamaan anak-anak juga cenderung meniru.

g. Rasa heran atau kagum. Anak memiliki sikap keberagamaan heran atau kagum yang tidak disertai sikap kritis dan kreatif. ${ }^{24}$

Memahami sikap keberagamaan seseorang harus disesuaikan dengan karakteristik sikap keberagamaan yang dimilikinya. Sikap keberagamaan pada anak-anak tumbuh mengikuti pola ideas concept on authority. Maksudnya adalah konsep-konsep keagamaan pada anak sangat dipengaruhi oleh unsur-unsur yang berasal dari luar dirinya. ${ }^{25}$ Anak-anak cenderung mengikuti apa yang diajarkan dan dikerjakan oleh orang-orang yang ada di sekelilingnya. Orang dewasa terutama orang tua sangat berperan dalam membentuk konsep keberagamaan pada anak. Anak-anak sangat mudah menerima ajaran dari orang dewasa walaupun ajaran itu belum disadari sepenuhnya tujuan dan manfaat dari ajaran tersebut.

Sikap keberagamaan remaja berbeda dengan anak-anak. Zaikah Darajat mengemukakan beberapa karateristik sikap keberagamaan remaja, yaitu :

a. Kepercayaan turut-turutan

Kebanyakan remaja menjalankan ajaran agama disebabkan karena faktor lingkungan. Orang tuanya, teman-temannya dan masyarakat sekelilingnya percaya dan rajin beribadah, maka remaja ikut percaya dan melaksanakan ibadah. Remaja cenderung mengikuti suasana lingkungan yang ada di tempat tinggalnya. Sikap keberagamaan seperti ini disebut percaya turut-turutan.

b. Percaya dengan kesadaran

Remaja berada dalam masa transisi dari anak-anak menuju dewasa. Sikap keberagamaan remaja juga berada dalam keadaan peralihan dari kehidupan beragama anak menuju pada masa kemantapan beragama. Oleh karena itu,

\footnotetext{
${ }^{23}$ Ramayulis, Psikologi Agama, (Jakarta: Kalam Mulia, 2011), h. 57-59

${ }^{24}$ Ibid., h. 60-62

25 Ibid., h. 56
} 
remaja mulai untuk menemukan pengalaman dan penghayatan terhadap ajaran agama yang diyakininya.

c. Percaya tapi agak ragu-ragu (bimbang)

Keraguan dalam dalam beragama remaja dapat dikelompokkan menjadi dua, yaitu:

1) Keraguan karena adanya goncangan yang disebabkan terjadinya proses perubahan dalam pribadinya. Goncangan seperti ini wajar dialami oleh setiap remaja.

2) Keraguan karena apa yang dimiliki tidak sesuai dengan kenyataan yang dialaminya. Misalnya ketika masa anak-anak ditanamkan agar berakhlak dan bertingkah laku sesuai dengan ajaran agama, tetapi kenyataan menunjukkan banyak terjadi kemerosotan moral di lingkungan masyarakat.

d. Tidak percaya sama sekali atau cenderung pada atheis

Keraguan beragama pada remaja bila sudah memuncak dan tidak bisa di atasi, maka akan menimbulkan kebingungan pada remaja, bahkan dapat menimbulkan kebimbangan dan keingkaran remaja pada agama. Hal ini sesungguhnya bukan berarti bimbang dan ingkar yang sungguhnya, melainkan hanya sebagai salah satu bentuk atau cara untuk menyampaikan protes terhadap ajaran agama yang diyakini selama ini tidak sesuai dengan kenyataan atau yang diharapankan, seperti karena kecewa, sakit hati, menderita yang bertumpuktumpuk dan sebagainya, sehingga berputus asa terhadap keadilan dan kekuasaan Tuhan. Keadaan seperti ini bila dibiarkan akan muncul rasa benci dan enggan menjalankan ajaran agama yang selama ini diyakininya. ${ }^{26}$

Lain halnya dengan sikap keberagamaan orang dewasa. Orang dewasa memiliki sikap keberagamaan yang luas sesuai dengan niilai-nilai yang diyakininya. Sikap keberagamaan yang dimiliki oleh orang dewasa didasarkan pada pendalaman makna dan pemahaman terhadap ajaran agama yang diyakininya. Beragama bukan hanya sekedar ikut-ikutan, tetapi sudah menjadi sikap hidup. Ada beberapa ciri sikap keberagamaan orang dewasa, yaitu :

a. Kebenaran agama diterima berdasarkan pertimbangan pemikiran yang matang bukan sekedar ikut-ikutan.

b. Bersifat realistis, artinya ajaran agama banyak direalisaikan dalam sikap dan perilaku kehidupan sehari-hari.

c. Punya sikap yang positif terhadap ajaran agama

d. Berusaha mempelajari dan mendalami ajaran agama yang diyakininya.

${ }^{26}$ Zakiyah Daradjat, Ilmu Jiwa Agama... h. 91-93. 
e. Ketaatan dalam beragama dilandaskan pada pertimbangan yang matang dan rasa tanggung jawab.

f. Memiliki wawasan dan pengetahuan keberagamaan yang lebih luas serta bersifat kritis terhadap materi ajaran agama yang diyakininya.

g. Dalam menerima, memahami dan mengamalkan ajaran agama dipengaruhi kepribadian yang dimilikinya. ${ }^{27}$

Untuk memahami sikap individu biasanya tidak mudah. Oleh karena itu diperlukan beberapa metode. W. A. Gerungan menjelaskan bahwa untuk memahami sikap terdapat beberapa metode, yaitu : Pertama, metode langsung, yaitu metode untuk mengetahui sikap individu di mana individu secara langsung diminta pendapatnya atau tanggapannya mengenai objek tertentu. Kedua, metode tidak langung. Metode ini terdiri dari dua macam, yaitu metode tes tersusun dan tes tidak tersusun. Metode tes tersusun dilakukan dengan menggunakan tes skala sikap, seperti tes skala likert, guttman dan sebagainya. Tes tidak tersusun dilakukan dengan wawancara, daftar pertanyaan biasa, biografi, kepustakaan dan sebagainya. ${ }^{28}$

\section{Komponen-komponen dan bentuk-bentuk sikap keberagamaan}

Sikap memiliki beberapa komponen. Menurut Travers, Gagne dan Cronbach sebagaimana dikutip oleh Abu Ahmadi, menjelaskan bahwa sikap memiliki tiga komponen, yaitu :

a. Komponen kognitif. Komponen ini menyangkut semua pengetahuan, pikiran dan keyakinan yang dimiliki diperoleh melalui berbagai informasi terkait suatu objek.

b. Komponen afektif, yaitu segala sesuatu yang terkait emosi individu terhadap suatu objek. Emosi ini biasanya diiringi dengan rasa suka atau tidak suka, senang atau tidak senang dan sebagainya.

c. Komponen behavior atau konatif, yaitu komponen yang melibatkan salah satu predesposisi untuk bertindak terhadap suatu objek. ${ }^{29}$

Komponen behavior atau konatif sangat dipengaruhi oleh komponen kognitif. Komponen behavior atau konatif terkait dengan kecenderungan untuk melakukan sesuatu. Dalam literatur lain komponen behavior disebut juga dengan action tendency. Sikap positif individu terhadap suatu objek akan memicu munculnya perbuatan untuk membantu, memperhatikan, dan berbuat sesuatu yang menguntungkan terhadap suatu objek. Sebaliknya, sikap negatif terhadap

\footnotetext{
27 Ramayulis, Psikologi Agama... h. 78-79

${ }^{28}$ W. A. Gerungan, Psikologi Sosial... h. 166

${ }^{29}$ Abu Ahmadi, Psikologi Sosial, (Jakarta: Renika Cipta, 1991), h. 165
} 
suatu objek akan memunculkan perbuatan untuk mengancam, mencela, menyerang bahkan membinasakan objek tersebut.

Seorang psikolog bernama Gordon Willard Allport melakukan penelitian tentang pengaruh sikap keberagamaan seseorang terhadap kehidupannya. Apakah agama dapat memberikan dorongan yang positif atau negatif terhadap kehidupan pribadi pemeluknya dan masyarakat sekitarnya? Dan apakah dengan menjadi beragama, seseorang dapat lebih bermanfaat bagi dirinya dan sesamanya? Untuk menjawab pertanyaan-pertanyaan ini, Allport terlebih dahulu mendefinisikan apa arti agama bagi seseorang. Arti agama ini selanjutnya akan berimplikasi terhadap perbuatannya.

Allport menyatakan bahwa ada dua macam sikap keberagamaan seseorang, yaitu: Pertama, sikap keberagamaan yang ekstrinsik. Sikap keberagamaan ekstrinsik, memandang agama sebagai something to use but not to live.30 Artinya agama dipandang sebagai untuk mencapai sesuatu dan bukan untuk kehidupan. Agama hanya digunakan sebagai alat untuk mencapai motif tertentu, seperti ingin dipuji, ingin dihormati, ingin dihargai, untuk mendapatkan kedudukan, jabatan dan sebagainya. Orang yang memiliki sikap keberagamaan seperti ini, biasanya dalam beragama hanya melaksanakan bentuk luar dari ajaran agama saja. Shalat, puasa, zakat dan haji dikerjakan, tapi pesan moral dari ibadah yang dikerjakan tidak diimplemetasikan dalam kehidupan nyata. Ibadah dikerjakan, tetapi perbuatan maksiat tetap juga dilaksanakan.

Sikap keberagamaan seperti ini menurut Allport, tidak akan pernah melahirkan pribadi-pribadi yang terpuji akhlaknya maupun masyarakat yang penuh dengan cinta damai, bahkan sebaliknya hanya akan melahirkan pribadipribadi yang tercela dan masyarakat yang penuh dengan kebencian dan iri hati. Susah melihat saudaranya senang dan senang melihat saudaranya susah. Sikap keberagamaan seperti ini, boleh jadi merupakan salah satu jawaban dari pertanyaan "Mengapa Bangsa Indonesia yang mayoritas penduduknya muslim justru belum mampun menempatkan bangsa ini menjadi yang bebas dari korupsi?". Suap-menyuap, korupsi, kolusi, dan nepotisme sudah menjadi budaya bangsa ini, serta dekadensi moral yang terus semakin memprihatinkan dan membuat bangsa ini semakin terpuruk. Mungkin ini semua dikarenakan karena mayoritas penduduk muslim di negeri ini masih memiliki sikap keberagamaan secara ekstrinsik.

Kedua, sikap keberagamaan instrinsik. Sikap keberagamaan instrinsik artinya memandang agama sebagai kekuatan yang mengontrol kehidupan. ${ }^{31}$ Agama merupakan sekumpulan prinsip-prinsip yang mengatur kehidupan seseorang dalam semua bentuk interaksi. Singkatnya, agama dijadikan sebagai

\footnotetext{
${ }^{30}$ Robert W. Crapps, Dialog Psikologi dan Agama, (Yogyakarta: Kasinus, 1993), h. 178

${ }^{31}$ Ibid., h. 179
} 
pedoman dalam kehidupannya. Shalat, puasa, membayar zakat, dan haji dilaksankan. Begitu juga dengan sikap dan perbuatan sehari-harinya mencerminkan keperibadian orang yang shalat. Tindak-tanduknya dalam berinteraksi selalu berpedoman kepada agamanya. Tujuan puasa untuk membentuk insan yang bertaqwa teraplikasikan dalam kehidupannya.

Pribadinya selalu menginginkan maju dan tumbuh bersama di bawah naungan ridha Allah SWT. Senang melihat saudaranya senang dan ikut susah melihat saudaranya susah. Sikap beragama seperti inilah menurut Allport yang akan mampu mewujudkan pribadi-pribadi yang terpuji akhlaknya dan masyarakat yang penuh dengan kedamaian, kasih sayang, pada gilirannya akan mewujudkan baldatun thayyibatun warobbun ghafur.

\section{Faktor-faktor yang mempengaruhi sikap keberagamaan}

Sikap yang dimiliki oleh seseorang berbeda-beda antara yang satu dengan yang lainnya. Perbedaan tersebut terlihat baik dari segi jenisnya maupun dari segi kualitasnya. Perbedaan sikap yang dimiliki oleh seseorang dipengaruhi oleh banyak faktor, diantaranya adalah keadaan keluarga, lingkungan sekolah, lingkungan masyarakat, kebudayaan, nilai, agama, adat-istiadat dan sebagainya. Secara garis besar Abu Ahmadi menjelaskan bahwa sikap seseorang dipengaruhi oleh dua faktor, yaitu:

a. Faktor internal. Faktor internal merupakan faktor yang ada di dalam pribadi individu. Faktor berperan sebagai selectivity, menyeleksi dan mengolah atau menganalisis berbagai pengaruh yang datang dari luar diri individu. Penetapan pilihan biasanya disesuaikan dengan motif dan sikap yang ada di dalam diri individu. Motif dan sikap di dalam diri individu erat kaitannya dengan minat dan perhatiannya. Menurut Ellis sebagaimana dikutip oleh M. Ngalim Purwanto, faktor internal yang sangat mempengaruhi sikap seseorang terhadap suatu rangsangan selain faktor minat dan perhatian adalah kematangan atau maturation dan keadaan fisik individu. ${ }^{32}$

b. Faktor eksternal. Faktor eksternal merupakan faktor yang berasal dari luar dari individu. Faktor ini berupa interaksi sosial baik di dalam kelompok maupun di luar kelompok.33 Mislanya antara individu dengan individu lain (dalam keluarga, sekolah dan lingkungan masyarakat), intraksi individu dengan hasil kebudayaan dan sebagainya.

Sherif sebagaimana dikutip oleh Abu Ahmadi menjelaskan bahwa sikap dapat dirubah dan dibentuk. Perubahan dan pembentukan sikap akan terjadi jika terdapat hubungan timbal balik dan komunikasi secara langsung antar

\footnotetext{
${ }^{32}$ M. Ngalim Purwanto, Psikologi Pendidikan... h. 142

${ }^{33}$ Abu Ahmadi, Psikologi Sosia... h. 171
} 
manusia. $^{34}$ Dengan kata lain pembentukan dan perubahan sikap terjadi tidak dengan sendirinya. Setidaknya adal tiga hal penting yang dapat mempengaruhi pembentukan dan perubahan sikap individu, yaitu :

a. Keluarga, lembaga pendidikan, lembaga keagamaan, organisasi kerja dan sebagainya.

b. Kelompk sebaya

c. Media massa. ${ }^{35}$

Menurut Stephen R. Covey (dalam Muhammad Ali) ada tiga teori yang terkait dengan pembentukan dan perubahan sikap, yaitu:

a. Teori determinisme genetic. Teori ini berpandangan bahwa sikap individu diwariskan secara turun temurun dari nenek moyangnya. ${ }^{36}$ Jika kakek-nenek seorang punya sikap mudah marah, maka seseorang itu akan memiliki sikap mudah marah juga. Pewarisan sikap seperti ini diteruskan dari satu generasi ke generasi berikutnya.

b. Teori determinasi psikis. Teori ini berpandangan bahwa sikap yang dimiliki oleh individu sangat dipengaruhi oleh pola asuh orang tua. ${ }^{37}$ Pola asuh orang tua yang diterima individu pada masa kanak-kanak membentuk pola dasar keperibadian dan karakter individu termasuk di dalamnya pembentukan sikap individu.

c. Teori determinisme lingkungan. Teori ini berpendapat bahwa pembentukan dan perkembangan sikap individu sangat dipengaruhi oleh perlakuan lingkungan terhadap individu tersebut. ${ }^{38}$ Perlakuan orang tua, saudara, guru, teman sebaya, atasan/pimpinan, pasangan, situasi ekonomi, atau kebijakankebijakan pemerintah, semuanya turut membentuk dan mempengaruhi perkembangan sikap setiap individu.

Menurut hemant penulis, sebenarnya yang dapat mempengaruhi pembentukan dan perubahan sikap khususnya sikap keberagamaan di samping faktor-faktor sebagaimana diuraikan di atas, juga dipengaruhi oleh :

a. Kualitas iman

Iman memiliki peran yang sangat penting bagi setiap muslim. Sikap dan perilaku keberagamaan setiap individu dalam pandangan Islam sangat ditentukan oleh kualitas keimanan. Semakin berkualitas iman seseorang, maka sikap dan perilaku keberagamaan yang dimunculkan akan semakin baik, begitu 2008), h. 143

${ }^{34}$ Ibid., h. 171

${ }^{35}$ Abu Ahmadi, Psikologi Sosia... h. 171

${ }^{36}$ Muhammad Ali, Perkembangan Peserta Didik, (Bandung: PT. Remaja Rosdakarya,

37 Ibid., h. 43

38 Ibid. 
juga sebaliknya. Oleh karena itu perubahan dan perkembangan sikap keberagamaan seseorang sangat ditentukan oleh kualitas keimanannya.

b. Ilmu pengetahuan

Untuk membentuk sikap keberagamaan seseorang di samping ditentukan oleh kualitas iman juga harus didukung ilmu pengetahuan. Pengakuan keimanan harus diwujudkan dengan amal perbuatan. Seseorang tidak akan dapat beramal secara baik apabila tidak memiliki ilmu pengatahuan tentang cara beramal. Oleh karena itu, iman dan ilmu merupakan satu kesatuan yang tidak bisa dipisahkan termasuk dalam pembentukan dan pengembangan sikap keberagamaan. Allah SWT menjanjikan akan mengangkat derajat orangorang beriman dan berilmu pengetahuan.

c. Lingkungan

Manusia sebagai makhluk sosial tidak bisa hidup sendiri tanpa berinteraksi dengan lingkungan. Lingkungan sangat mempengaruhi perkembangan setiap individu termasuk perkembangan sikap keberagamaan. Lingkungan yang baik akan memberikan pengaruh yang positif terhadap pertumbuhan dan pembentukan sikap keberagamaan individu, begitu juga sebaliknya. Oleh karena itu, kualitas keimanan, ilmu pengetauan dan lingkungan, (baik lingkungan keluarga, sekolah dan masyarakat) merupakan tiga aspek yang tidak dapat dipisahkan dalam pembentukan dan pengembangan sikap keberagamaan setiap individu.

Pebentukan dan pengembangan sikap bukan hanya tanggung jawab orang tua dan lembaga keagamaan semata. Tetapi sesungguhnya lembaga pendidikan memiliki peran yang sangat penting dalam pembentukan dan pengembangan sikap keberagamaan setiap individu. Profesionalitas guru, iklim sekolah yang mendukung, ketersediaan sarana dan prasarana serta perhatian pemerintah dan masyarakat turut andil dalam membantu lembaga pendidikan untuk membentuk dan mengembangkan sikap keberagamaan peserta didik.

\section{Perkembangan sikap keberagamaan}

Perkembangan sikap keberagamaan setiap individu berbeda-beda. Perbedaan ini terjadi akibat adanya perbedaan usia dan berbagai faktor yang mempengaruhinya, baik faktor dari dalam diri individu maupun faktor dari luar diri individu. Menurut penelitian Ernest Harms dalam bukunya The Development of Religious on Childen sebagaimana yang dikutip oleh Ramayulis, perkembangan sikap keberagamaan anak dapat dibagi menjadi tiga tingkatan, yaitu:

a. The fairy tale stage (tingkat dongeng)

Perkembangan sikap keberagamaan pada tingkat dongeng dimulai pada usia 3-6 tahun. Perkembangan sikap keberagamaan pada fase ini sangat dipengaruhi oleh daya fantasi dan emosi. Di sisi lain, pada fase ini daya 
intelektual individu belum berkembangn secara optimal. Oleh karena itu kehidupan pada masa anak-anak ini sangat dipengaruhi oleh daya fantasi dan emosinya, bahkan perkembangan sikap keberagamaan pun banyak menggunakan konsep fantasi yang diliputi oleh dongeng-dongeng yang kadangkadang kurang masuk akal. ${ }^{39}$

b. The realistic stage (tingkat kenyataan)

Perkembangan sikap keberagamaan pada tingkat kenyataan dimulai dari usia 6-13 tahun, atau dimulai usia masuk Sekolah Dasar sampai usia adolescence. Perkembangan sikap keberagamaan pada usia ini sudah mengarah pada konsepkonsep yang realistis. Sikap keberagamaan yang cenderung bersifat realistis ini diperoleh individu dari lembaga keagamaan dan pembelajaran dari orang dewasa. Perkembangan sikap keberagamaan tingkat kenyataan ini pada awalnya didasarkan atas dorongan emosional dan berlanjut sehingga melahirkan melahirkan konsep-konsep formalis dan realistis. ${ }^{40}$ Pada usia ini anak-anak sangat senang dan tertarik untuk mengikuti kegiatan keagamaan yang dilakukan oleh orang dewasa di lembaga keagamaan. Dari sinilah anak-anak mendapatkan pengalaman keberagamaan yang dipelajari dari orang dewasa.

c. The individual stage (tingkat individu)

Perkembangan sikap keberagamaan pada tingkat individu ini ditandai dengan adanya kepekaan emosi. Kepekaan emosi ini selanjutnya akan melahirkan konsep keagamaan yang bersifat individualistis. Sikap keberagaan pada tingkat ini dapat dikelompokkan menjadi tiga golongan, yaitu:

1) Sikap keberagaan konvensional dan konservatif. Pembentukan sikap keberagamaan konvensional dan konservatif dipengaruhi oleh sebagian kecil fantasi dan pengaruh dari luar dirinya.

2) Sikap keberagamaan murni yang dinyatakan melalui tanggapan dan pendapat yang bersifat personal.

3) Sikap keberagamaan humanistik. Pada tingkat ini agama sudah dijadikan sebagai etos humanistik dalam kehidupannya. ${ }^{41}$

Menurut Piaget, pada usia remaja dan dewasa individu berada pada fase perkembangan operasional formal. Pada fase ini individu sudah dapat berpikir abstrak, logis dan idealis. ${ }^{42}$ Pada usia remaja dan dewasa individu sudah mampu memahami ajaran-ajaran agama yang bersifat abstrak, mengkaji secara logis dan sistematis, serta mengamalkan nilai-nilai agama yang logis dan realistis.

\footnotetext{
${ }^{39}$ Ramayulis, Psikologi Agama... h. 55

40 Ibid

41 Ibid

${ }^{42}$ Santrock Santrock, Perkembangan Masa Hidup Jilid I... h. 44
} 
Di sisi lain, manusia dilahirkan ke muka bumi dilengkapi dengan potensi atau fitrah keberagamaan. Potensi atau fitrah keberagamaan ini berupa dorongan untuk mengabdikan diri kepada sang khalik. Dalam istilah lain dorongan keberagamaan tersebut dikenal dengan istilah bidayat al-diniyyat yang berupa potensi keberagamaan yang dianugerahkan Tuhan kepada manusia untuk dapat dikembangkan. Dengan adanya potensi ini adalah makhluk beragama. ${ }^{43}$

\section{Upaya mengembangkan sikap keberagamaan}

Setiap anak dilahirkan dengan potensi beragama. Potensi ini dapat dilihat saat anak memasuki usia 3-5 tahun yang ditandai dengan berbagai pertanyaan kritis terhadap apa yang dilihat dan didengar. Pertanyaan tersebut bersifat kritis tanpa disadari oleh orang tuanya. Misalnya anak bertanya siapa yang menciptakan manusia dan hewan, di mana dan siapa Allah, mengapa manusia disuruh shalat. Potensi beragama yang ada pada manusia sesuai dengan sabda Nabi SAW: "Setiap anak dilahirkan dalam keadaan suci, kedua orang tualah yang membuat mereka menjadi Yahudi, Nasrani dan Majusi". Hadits tersebut di samping menegaskan setiap individu dibekali dengan potensi keberagamaan, juga mengisyaratkan tentang pentingnya peran orang tua untuk mengembangkan dan mengarahkan potensi keberagaman yang dimiliki oleh setiap anak. Pengembangan dan pengarahan potensi keberagamaan anak harus dimulai sejak dini.

Langkah awal pengembangan dan pengarahan potensi keberagamaan dapat dilakukan dengan menanamkan nilai-nilai agama pada anak usia dini. Langkah ini sebagai tahap awal untuk menumbuhkan sifat, sikap dan perilaku keagamaan individu dan menjadi dasar untuk perkembangan pada masa berikutnya. Pada usia anak-anak karakter dasar sudah dapat dibentuk dan disesuaikan fungsi otak, emosional maupun religiusitasnya. Fase usia dini merupakan masa terbaik untuk menanamkan rasa dan sikap keberagamaan pada anak. Pada masa ini perkembangan sikap dan kesadaran keberagamaan masih pada tingkatan unrefictif (kurang mendalam) yang lebih banyak dipengaruhi oleh fantasi atau emosi dan imitatif (meniru) dari apa yang dilihat dan didengarnya. Secara spesifik karakteristik sikap keberagamaan pada anak usia dini adalah sebagai berikut :

a. Bersifat reseptif dan mulai banyak bertanya. Artinya anak akan menerima segala yang diberikan oleh orang tua atau pendidikannya termasuk nilainilai agama. Rasa ingin tahu yang dimiliki oleh anak sudah mulai tumbuh. Akibatnya anak akan selalu bertanya terhadap apa yang dilihat, didengar dan ucapan orang-orang di sekitarnya. Penjelasan yang benar dan mudah

\footnotetext{
${ }^{43}$ Jalaludin, Psikologi Agama...h. 64-67.
} 
diterima oleh anak sangat mempengaruhi pemahaman dan kesadaran agama di kemudian hari.

b. Pandangan ketuhanannya bersifat anthropomorphis (dipersonifikasikan) dan ideosyncritic (menurut khayalan). Artinya dalam memahami konsep Tuhan atau dalam menggambarkan Tuhan selalu diidentikkan dengan makhluk yang dilihatnya. Khayalan yang ada dalam pikiran anak lebih bersifat emosional. Pada masa ini anak belum bisa menerima konsep-konsep yang bersifat abstrak atau tidak terlihat.

c. Penghayatan secara ruhaniah masih superficial (belum mendalam atau ikutikutan), artinya dalam menjalankan perintah keagamaan sekedar partisipatif, meniru dan ikut-ikutan tanpa disadari penghayatan ruhaniahnya atau batiniahnya. ${ }^{44}$ Sering kali kita lihat anak-anak mengaji dan shalat berjamaah di masjid dengan main-main, berlari-lari atau bercanda dengan temannya. Hal ini disebabkan pada masa ini belum berkembang perasaan keberagamaan seperti rasa rendah hati, syukur, khusyu', atau takut terhadap azab Allah.

Untuk menanamkan, menumbuhkan dan mengembangkan sikap keberagamaan pada anak usia dini, di samping harus dilakukan sesuai dengan tingkat perkembangan kognitifnya dan emosinya, juga harus disesuaikan tingkat kesadaran beragamanya. Tingkat kesadaran agama atau keimanan anak masih pada tingkat stimulus response verbalisme (respons di bibir saja). Maka metode yang bisa diterapkan dalam menanamkan, menumbuhkan dan mengembangkan sikap keberagamaan pada anak usia dini adalah pengondisian lingkungan yang mendukung terwujudnya internalisasi nillai-nilai dan sikap keberagamaan pada diri anak, diantaranya melalui:

a. Keteladanan orang tua dan orang di sekitarnya. Sikap keberagamaan pada anak pada dasarnya adalah bersifat imitatif atau meniru, maka keteladanan dari orang tua dan orang-orang yang ada di sekitarnya memberikan kontribusi yang besar dalam menamkan, menumbuhkan dna mengembangkan sikap keberagamaan pada anak. Anak-anak cenderung akan meniru apa yang dilihat, didengar dan dialaminya. Sikap keberagamaan yang buruk, tidak shalat misalnya, sesungguhnya berkembang pada diri anak disebabkan karena anak sering melihat orang-orang di sekelilingnya tidka salat dan sebagainya.

b. Sugesti dan koreksi. Anak cenderung mengulang apa yang diucapkan dan apa yang dilakukan jika mendapatkan sugesti. Anak diberikan sugesti jika mengucakan atau melakukan suatu kebaikan, dan apabila melakukan sesuatu yang tidak sesuai dengan ajaran agama harus dilakukan perbaikan sesuai

${ }^{44}$ Abdul Azis Ahyadi, Psikologi Agama: Kepribadian Muslim Pancasila, Jakarta: Sinar Baru Algensindo, 1999), h. 40-43 
dengan ketentuan agama yang sebenarnya. Hal ini harus dilaukan secara kontiniu dan tanpa henti.

c. Dorongan sosial. Agama pada dasarnya dilaksanakan bukan hanya untuk kepentingan peribadi semata, tetapi agama juga berperan untuk kemaslahatan umat. Orang yang memiliki sikap keberagamaan yang baik buka hanya diukur dari ketaatannya dalam beribadah kepada Allah SWT semata melainkan juga harus memiliki hubungan sosial yang baik. Agar hubungan sosial anak dapat berkembang secara baik, maka sikap menghargai pendapat anak, memberikan kebebasan berkreasi, dan memberikan waktu bersosialisasi dengan teman-temannya perlu untuk dilakukan guna untuk mengembangkan nilai-nilai agama yang diperolehnya.

Pengkondisian lingkungan yang mendukung tumbuh dan berkembangnya sikap keberagamaan anak harus dimulai dari lingkungan terkecil yaitu keluarga. Keluarga merupakan lingkungan pertama dimana anak memperoleh segala pengetahuan dan mengenal adanya interaksi sosial (hubungan antara ayah, ibu dan anak). Rasa ketergantungan anak pada orang tua dan orang yang lebih dewasa sangat besar, sehingga peran orang tua atau orang yang lebih dewasa sangat penting dalam pendidikan agama pada usia tersebut.

Anak-anak memiliki karakteristik yang berbeda dengan orang dewasa. Cocok untuk orang dewasa belum tentu cocok bagi anak. Oleh karen itu jika menginginkan agar agama mempunyai arti bagi anak-anak, maka agama hendaklah disajikan sesuai dengan karakteristik anak, bersifat kongrit, menggunakan bahasa yang dipahami oleh anak-anak, dan kurang bersifat dogmatis. Anak pada umumnya menginginkan supaya kebutuhannya untuk tahu atau curiosity dapat terpenuhi.

Menurut Zakiah Darajat pembentukan sikap keberagamaan pada anak harus dilakukan sejak dini. Hal ini dapat dilakukan dengan cara memberikan pengalaman beragama kepada anak mulai dari lingkungan keluarga, sekolah dan masyarakat. ${ }^{45}$ Semakin banyak pengalaman beragama yang didapat oleh anak, makan akan semakin bagus perkembangan sikap keberagamaan pada anak. Zakiah Darajat lebih lanjut menjelaskan bahwa, salah satu yang dapat dilakukan untuk memberikan pengalaman beragama kepada anak adalah melalui pembinaan dan pembiasaan.

Semua orang menginginkan anaknya agar menjadi anak baik, soleh, berkepribadian yang kuat, sehat, mempunyai sikap keberagamaan yang baik dan akhlak terpuji. Semuanya itu dapat dilakukan melalui proses pendidikan, baik formal maupun informal. ${ }^{46}$ Pengalaman yang diperoleh anak baik melalui penglihatan, pendengaran maupun perlakuan yang diterima dalam proses

\footnotetext{
45 Zakiyah Daradjat, Ilmu Jiwa Agama... h.. 55

${ }^{46}$ Ibid., h.. 56
} 
pendidikan juga turut menentukan pembentukan dan pengembangan sikap keberagamaan anak.

Perlakuan, cara hidup dan sikap orang tua, perhatian, kasih sayang, pengertian dan sikap terbuka akan memudahkan dalam pembentukan sikap keberagamaan pada anak. Hal ini disebabkan karena anak mendapat ruang yang cukup dan baik untuk tumbuh dan berkembang. Sebaliknya, hubungan orang tua yang kurang harmonis, penuh perselisihan dan percekcokan akan menjadikan sikap dan pribadi anak sukar untuk dibentuk. Hal ini disebabkan karena anak tidak mendapatkan suasana yang baik untuk berkembang, perkembangan anak terganggu oleh suasana ketidaharmonisan orang tuanya.47

Selain itu, pengalaman-pengalaman keagamaan dapat diberikan oleh orang tua melalui perbuatan dan latihan, misalanya kebiasaan shalat berjamaah, cara bicara, buang air, mandi makan, minum dan sebagainya penting untuk dilakukan. Pengalaman-pengalaman keagamaan yang sudah dimiliki oleh anak yang diperoleh di rumah, akan mempengaruhi sikapnya di sekolah terhadap guru dan teman-temannya. Perbuatan dan latihan terkait dengan sikap keberagamaan hendaklah dilakukan dengan memberikan rasa nyaman dan aman kepada anak. Apabila latiah-latihan keberagamaan diberikan dengan cara yang kaku, salah dan tidak cocok dengan perkembangan anak, maka ketika dewasa justru anak akan cenderung kurang peduli terhadap agama.48

Guru mempunyai tugas yang cukup berat. Guru mempunyai tugas untuk membina keperibadian dan sikap anak, di samping mengajarkan pengetahuan kepada anak. Guru harus mampu memperbaiki sikap dan kepribadian anak yang sudah terlanjur rusak karena pendidikan dalam keluarga. Guru juga harus mampu mendukung dan mengembangkan sikap dan kepribadian yang sudah baik yang diperoleh anak dalam keluarga. Oleh karena itu, di samping memberikan pendidikan dan pengajaran kepada anak, guru juga dituntut menampilkan keperibadian, sikap, cara bergaul, cara hidup, cara bicara dan sebagainya yang layak dicontoh dan ditiru oleh anak.

Dalam upaya pengembangan sikap keberagamaan, keluarga, sekolah dan masyarakat memiliki peran yang sangat penting. Ada beberapa hal yang dapat di sekolah dalam rangka mengembangkan sikap keberagamaan siswa, diantaranya adalah :

a. Internalisasi nilai-nilai keagamaan. Internalisasi nilai-nilai keagamaan dapat dilakukan dengan memberikan pemahaman tentang nilai-nilai keberagamaan kepada para peserta didik. ${ }^{49}$ Internalisasi nilai-nilai agama di sekolah bukan

\footnotetext{
${ }^{47}$ Ibid

${ }^{48}$ Ibid., h.. 41

${ }^{49}$ Muhaimin, Rekonstruksi Pendidikan Islam; Dari Paradigma Pengembangan, Manajemen Kelembagaan, Kurikulum bingga Strategi Pembelajaran, (Jakarta: Raja Grafindo Persada, 2009), h. 325
} 
hanya dilakukan melalui pendidikan dan pengajaran pada mata pelajaran pendidikan agama, tetapi harus diimplementasi pada semua mata pelajaran.

b. Menciptakan suasana religius, yaitu mengkondisikan seluruh suasana sekolah dengan nilai-nilai dan perilaku religius. ${ }^{50}$ Penciptaan suasana religius dapat dilakukan dengan menciptakan sarana dan prasarana sekolah bernuansa religius, memberikan keteladanan, pembiasaan, pencipaan sikap dan perilaku religius dan sebagainya. Kesemuanya itu harus dilakukan dengan penuh kesadaran dan komitmen seluruh personil sekolah tanpa terkecuali.

\section{Kesimpulan}

Sikap keberagamaan merupakan suatu keadaan internal individu yang menyebabkan munculnya kesiapan individu untuk merespon atau bertingkahlaku sesuai dengan ajaran agama. Sikap keberagamaan merupakan perolehan dan bukan bawaan. Sikap keberagamaan terbentuk melalui pengalaman langsung yang terjadi dalam hubungannya dengan unsur-unsur lingkungan dan sosial, misalnya interaksi individu dengan hasil kebudayaan, orang tua, guru, teman sebaya, orang tertentu, masyarakat dan sebagainya. Lingkungan keluarga, sekolah dan masyarakat memiliki peran yang sangat penting dalam pembentukan dan pengembangan sikap keberagamaan setiap individu.

Karakteristik dan perkembangan sikap keberagamaan individu berbedabeda, sesuai dengan tahap-tahap perkembangan. Sikap keberagamaan yang dimiliki oleh individu terbentuk melalui tiga komponen, yaitu komponen kognitif, afektif dan konatif. Oleh karena itu pembentukan dan pengembangan sikap keberagamaan individu baik dari aspek kognitif, afektif dan konatif harus disesuaikan dengan karakteristik dan tahap-tahap perkembangan individu. Hal ini dapat dilakukan dengan cara, yaitu : Pertama, internalisasi nilai-nilai keislaman melalui keteladana, sugesti dan koreksi, dan dorongan sosial. Kedua, menciptakan lingkungan religius baik di keluarga, sekolah maupun di masyarakat. 


\section{Bibliografi}

Abdul Azis Ahyadi, 1999, Psikologi Agama: Kepribadian Muslim Pancasila, Jakarta: Sinar Baru Algensindo

Abu Ahmadi, 1991, Psikologi Sosial, Jakarta: Renika Cipta

Ahmad Tafsir, 2005, Metodologi Pengajaran Agama Islam, Bandung: PT. Remaja Rosdakarya

Arham, A. (2016). Pengaruh Pembinaan Kegidupan Beragamaan dalam Keluarga terhadap Sikap Keberagamaan Peserta Didik SDN 74 Tamarellang Auladuna: Jurnal Pendidikan Dasar Islam, 3(1), 11-15

Asmaul Sahlan, 20-09, Mewujudkan Budaya Relijius di Sekolah: Upaya mengembangkan PAI dari Teori ke Aksi, Malang: UIN-Maliki Press

Crapps, Robert W., 1993, Dialog Psikologi dan Agama, Yogyakarta: Kasinus

Departemen Pendidikan dan Kebudayaan, 1991, Kamus Besar Bahasa Indonesia, Jakarta: Dep. P dan K

Jalaludin, 2011, Psikologi Agama, Jakarta: Rajawali Press

Jalaludin Rahmad, 2001, Psikologi Agama: Sebuah Pengantar, Jakarta: PT. Raja Grafindo Persada

Irwansyah, I. (2014). Perbedaan Sikap Keberagamaan Antara Masyarakat Islam dan Kristiani di Sumatera Utara dan Frankfurt Am Main Jerman. ISLAMICA: Jurnal Studi Keislaman, 9(1), 30-53

Ismail dan Fahmi (2017). Internalisasi Sikap Keberagamaan sejak Usia Dini, Vol 1 No. 1: Raudhatul Athfal: Jurnal Pendidikan Islam Anak Usia Dini: jurnal.radenfatah.ac.id

M. Ngalim Purwanto, 2004, Psikologi Pendidikan, Bandung : PT Remaja Rosdakarya

Muhaimin, 2009, Rekonstruksi Pendidikan Islam; Dari Paradigma Pengembangan, Manajemen Kelembagaan, Kurikulum hingga Strategi Pembelajaran, Jakarta: Raja Grafindo Persada

Muhammad Ali, 2008, Perkembangan Peserta Didik, Bandung: PT. Remaja Rosdakarya

Noer, H. A., Tambak, S., \& Rahman, H. (2017). Upaya Ekstrakurikuler Kerohanian Islam (ROHIS) dalam Meningkatkan Sikap Keberagamaan Siswa di SMK Ibnu Taimiyah Pekanbaru. Jurnal Pendidikan Agama Islam Al-Thariqah, 2(1), 21-38

Ramayulis, 2011, Psikologi Agama, Jakarta: Kalam Mulia 
42 | ISLAMIC COUNSELING : Jurnal Bimbingan dan Konseling Islam, vol. 2, no. 1, 2018

Santrock,2004, Perkembangan Masa Hidup Jilid I, Jakarta, Erlangga

Saifuddin Azwar, 1995, Sikap Manusia: Teori dan Pengukurannya, Yogyakarta: Pustaka Pelajar

Tampubolon, I. (2016). Struktur Paradigmatik Ilmu-ilmu Keislaman Klasik: Dampaknya terhadap Pola Pikir, Sikap, dan Perilaku Keberagamaan. MIQOT: Jurnal Ilmu-ilmu Keislaman, 37(2)

W.A. Gerungan, 2009, Psikologi Sosial, Bandung : Rafika Aditama

Zakiyah Daradjat, 2003, Ilmu Jiwa Agama, Jakarta, PT: Bulan Bintang 